\title{
Teaming Up and Out? Getting Durable Cooperation in a Collegial Organization
}

Emmanuel Lazega

Obtaining durable cooperation from peers and associates is a delicate matter in collegial organizations because members often value the ideology of autonomous professional action. This paper contributes to the explanation of members' solidarity and firm integration in such organizations. Looking at the ways in which work is taken in and assigned in a medium-sized Northeastern US corporate law partnership, it focuses on two forms of workflow-related solidarity, called welfare and patronage. The latter form, however, represents a threat of opportunistic behaviour by powerful rainmakers, that of defection by 'teaming up and out'. The firm is shown to have found a structural solution to this problem. Using a network study of members' choices of strong coworkers, members can be portrayed as niche-seeking entrepreneurs in need of lasting and dependable co-workers. In turn, niche-seeking by individuals is shown to create a structure in which representatives of the welfare system succeed in preventing easy defection by patrons who would like to increase the size of their workforce. This solution to the problem of integration is thus likely to be a 'Montesquieu structure' that balances the power of different forms of status in this type of organization and helps the two solidarity systems to coexist via their interdependence. A multi-level approach combines interests analysis and network analysis at the dyadic and structural levels to look at this solution.

\section{Introduction}

Getting durable cooperation from peers and associates is not a straightforward matter in collegial organizations (Waters, 1989; 1993). The ideals of professionalism as a culture of motivation, the complexity and non-routine character of tasks, and the relative unpredictability of clients' behaviour are important factors explaining why such organizations do not find truly bureaucratic solutions to this problem. Professional members value the ideology of autonomous action (Freidson, 1976; Sciulli, 1986). In such a situation, what are the social mechanisms of solidarity and control that help collegial organizations maintain cooperation and prevent defection, a form of opportunistic behaviour?

Understanding durable cooperation among autonomous professionals is of value to more gen- eral sociological theory because it shows that such mechanisms can only be understood when a broadly conceived rational choice approach is combined with structural analysis. Theory for such a combination has been available for a long time (Crozier and Friedberg, 1977; Lindenberg and Wippler, 1978; Boudon, 1981; Hechter, 1987; Coleman, 1990; Blossfeld and Prein, 1998; Esser, 1998; Hedström and Swedberg, 1998). However, actual empirical work bridging the levels of analysis is scarce. This paper contributes to a multi-level approach to solidarity and integration in collegial organizations. I argue that individual action produces unexpected effects at the structural level that are important to group solidarity because they help members maintain an integration based on their interdependencies. 
This paper examines a situation in a mediumsized Northeastern US corporate law firm, in which members have access to cooperation through two possible mechanisms of work allocation: an official welfare system and an informal patronage system. To survive in such an organization, interdependent members of the firm need access to resources such as work for clients (not always very easy to find in the beginning of the $1990 \mathrm{~s}^{1}$ ) and goodwill from cooperative manpower. In this context, solidary behaviour means that a member is prepared to help out another member who finds him/herself in a difficult situation with regard to such needs (Lindenberg, 1998). For example, this includes changing one's priorities for a while because Alter faces an urgent deadline for a client. Or systematically selecting Alter (as opposed to others) as a coworker on an interesting and visible case brought into the firm. Or exercising restraint by not trying to grab all the credit in a successful case conducted in conjunction with Alter.

The organization helps members gain access to such resources and solidary behaviour. It conducts its affairs based on formal rules, which express choices among policy options, and allocate, directly and indirectly, these resources to members (Rowley and Rowley, 1960). Authority to handle new files or clients (intake) or to allocate this new work among colleagues (assignment) is distributed more or less formally. For many members (partners and associates), access to work opportunities depends on these intake and assignment policies. A basic 'welfare system' is established, i.e. a committee that allocates such resources across professional members of the firm and helps organize cooperation. In spite of their boring aspect, procedures of intake (mainly, whether or not to take in a case) and assignment (mainly, who will do the work) are thus good indicators of solidary behaviour.

In theory, members of the firm know about such formal arrangements and order their professional lives accordingly. But in reality many often behave differently. For reasons which will be described, they do not necessarily trust or count on the official welfare system to obtain cooperation from one another and provide solidarity. They can have strong interests in not doing so. For instance, partners have strong incentives to keep control of the files for clients that they bring into the firm, and to use the best possible peers and associates to do the work. Associates are required to bill a minimum number of hours in the year, and have personal incentives to work with influential partners who will carry weight on the day of the decision about their promotion to partnership. Thus, files are not all allocated by the formal channels; members cooperate through other channels. Clientelistic ties and more selective solidarities can be established between, on the one hand, patrons with control of access to the market and, on the other hand, more dependent colleagues. The welfare system is thus intertwined with an informal patronage system. Members thus have a choice between gaining access to cooperation through welfare or through patronage. Each can respond to their interests and solve their problem differently, although the clientelistic match-making process is not formally allowed.

First, ethnographic evidence is provided for the existence of the two forms of solidarity in this collegial organization. I show that each type of solidarity is organized by partners with a different form of status. The first is organized by 'minders', the second by 'finders' or 'rainmakers' who establish clientelistic ties with 'grinders' (junior partners, sometimes called 'baby partners', or associates). These qualifications are mainly borrowed from Nelson (1988) who shows that, in spite of a set of rules which tries to smooth the hierarchical nature of their business, law firms are very much stratified organizations. Their authority system is based on a distinction between these finders, minders, and grinders. With a few exceptions, the finders are partners who find new and lucrative clients, and bear the greatest responsibility for them. Their governing authority is not as formal and as permanent as that of their corporate analogues. Directives are reached by a form of gentlemen's agreement. The minders are partners with managerial roles and responsibility for long-established clients. The managerial role in large firms arises from the necessity of coordinating diverse practice areas, promoting an efficient organization of work, and decentralizing control over a large professional staff working on highly specialized matters. As seen by Blau (1964: 50), 'minders cease to compete for superior status and win social acceptance in the group in exchange for the contribution they make to group solidarity'. Minders typically serve on administrative 
committees. The grinders are other lawyers who perform the actual legal work, who either function as little more than salaried staff, or associates who are subject to the demands of partners.

Second, a social mechanism is described that helps minders maintain firm integration when facing threats of defection by finders. In effect, this situation creates a threat to firm integration because patronage tends to build up teams of specialized members who are in a position to defect. In such professional partnerships, the existence of patronage often represents a danger of disintegration for the firm. Clientelistic solidarity among partners or between partners and associates can create stable workgroups that may defect from the firm, taking lucrative clients away with them. Thus, in such a situation, members' choice of either welfare or patronage to obtain cooperation raises a typical problem of collective action. The logic underlying such a choice is examined by looking at members' selection of strong co-workers. A systematic network study of the firm allows analysis of such choices both at the dyadic and at the structural level (see for example White, 1985; Burt, 1982). At the dyadic level, analysis shows members' tendency to value specific similarities among themselves and therefore a logic of action that relies on nicheseeking (Lazega, 1992; 1999b; forthcoming). They see it to be in their interest to seek reliable coworkers among colleagues in the same office, same specialty, and sometimes same hierarchical status. This logic is that of niche-seeking 'intrapreneurs' who find durable cooperation among their colleagues by looking for contexts in which these ties have more chances than otherwise to provide this resource on a generalized exchange basis (Lazega and Pattison, 1999).

This niche-seeking logic in actors' choices is then shown to have an effect on the coexistence of the two solidarity systems (welfare and patronage) because it creates a structure in which minders occupy a position that helps them prevent finders from mustering the specialized manpower necessary for easy defection. Niche-seeking structures the organization in a way that is likely to help minders in their efforts to control finders and their threat of opportunistic behaviour. This structure is called a 'Montesquieu structure' because it reflects the existence of a partial political order. Retrospectively, one of the goals of intake and assignments procedures appears to be to prevent the creation of 'ready-foreasy-defection' workgroups within such niches.

A multi-level approach combining interests analysis and structural analysis thus looks at this new picture of the work process and at the structural solution provided by the minders of a collegial organization to the problem of firm solidarity and integration.

\section{Cooperation under a Partnership Agreement}

Fieldwork was conducted at Spencer, Grace \& Robbins, ${ }^{2}$ a Northeastern US corporate law firm (71 lawyers in three offices, comprising 36 partners and 35 associates), in 1991. All the lawyers in the firm were interviewed. In Nelson's (1988) terminology, this firm is a 'traditional' one, without formally defined departments, as opposed to a more 'bureaucratic' type. Interdependence among attorneys working together on a file may be strong for a few weeks, and then weak for months. As a clientoriented, knowledge-intensive organization, it tries to protect its human capital and social resources, such as its network of clients, through the usual policies of commingling partners' assets (clients, experience, innovations) (Gilson and Mnookin, 1985; Galanter and Palay, 1991) and the maintenance of an ideology of collegiality. Informal networks of collaboration, advice, and 'friendship' (socializing outside), are key to the integration of the firm (Lazega, 1992).

The partnership agreement sets clear groundrules as to each partner's rights and responsibilities in connection with compensation issues and withdrawal terms, and for the operation of the firm itself (Eickemeyer, 1988). Although not departmentalized, the firm breaks down into two general areas of practice: the litigation area (half the lawyers of the firm) and the 'corporate' area (anything other than litigation). Smigel (1969), Laumann and Heinz (1977), and Nelson (1988) have established the interdependence of specialties in generalist professional firms. Sharing work and cross-selling among partners at $\mathrm{SG} \& \mathrm{R}$ is done mostly on an informal basis, although less so among lawyers in general when including associates. Work is supposed to be 
channelled to associates through a specific committee of partners, the Assignment and Training Committee (ATC), but this rule is only partly respected. Partners' compensation is based exclusively on a seniority lockstep system without any direct link between contribution and returns. The firm goes to great lengths - when selecting associates to become partners - to take as few risks as possible that they will not 'pull their weight'. Partners may argue informally about what contribution might 'fairly' match one's benefits, but the seniority system mechanically distributes the benefits to each once a year.

Great managerial resources are devoted to measurement of each partner's performance (time sheets, billing, collecting, expenses, etc.), and this information is available to the whole partnership. A low level of performance cannot be hidden for long. However, such firms usually make considerable profits, which may help partners overlook the fact that some voluntary contributions to shared benefits may not always be consistent with the successful pursuit of narrow self-interest. In extreme cases, partners have the power to 'punish' each other seriously by preventing a partner from reaching the next seniority level in the compensation system. A partner can be expelled only if there is nearunanimity against him/her. Buying out a partner is very difficult and costly. Therefore, despite the existence of direct financial controls, the firm does not have many formal ways of dealing with freeloading. Rules against this are likely to be inefficient. For example, a goodwill clause and safeguards against defection do not work here because it is too difficult to prove that defectors took away a client with them. Clients do what they want. Therefore the harm that a single partner can inflict on others might become very substantial in the long run. Conversely, partners can try to isolate one of their own informally by, at the very least, not referring clients, not 'lending'associates, or not providing information and advice. Lateral control is thus especially important for curbing opportunistic behaviour in this firm (Lazega, 1995a; 2000; Lazega and Krackhardt, 2000).

Given the informality of the organization, a weak administration provides information, but does not have many formal rules to enforce. The firm has an executive committee made of a managing partner and two deputy-managing partners (respectively Partners 20, 5, and 26) who are elected each year, renewable once, among partners prepared to perform administrative tasks and temporarily transfer some of their clients to other partners. The current managing partner is not a 'rainmaker' and does not concentrate strong powers in his hands. He is a dayto-day manager who makes recommendations to the partnership or to its functional standing committees (finance, associate, marketing, recruitment, etc.). This formal structure does not mean that partners are actually equals. Even if partners are formally equals, some are 'more equal than others'. Partners who attract large clients or manage the firm wield more influence when important decisions are made. But formal egalitarianism among partners is maintained as a feature of their 'professionalism' (Waters 1989), and power retains a 'now you see it, now you don't' quality (Nelson 1988).

In sum, this law partnership is an interesting site for the study of group solidarity. Individual members have an interest in increasing collective profits and in thinking from a long-term perspective. They have to cooperate in order to reach this goal because the nature of the task often requires it. In order to produce their joint good (essentially, maximization of profit), the firm counts on the goodwill of its partners and obedience of its associates and other employees. In this system, individual members can be opportunistic in different ways: they can shirk or defect, individually or as a group. Their compliance to the rules of joint production cannot be taken for granted. It is bought by compensation, but that is not enough. The firm must count on members' commitment and sense of obligation. The degree to which members live up to this obligation is variable (Lazega, 1999b). The firm does not have many selective incentives for partners, although it has selective incentives for associates (the prospect of becoming partner).

In the next section, I provide ethnographic evidence showing the struggle between the two systems of solidarity.

\section{Welfare and Patronage in Managing Work}

Formal structure, the 'welfare system', attempts to coordinate the work process. In its effort to organize 
its practice, the firm formally regulates intake and assignment. There are many reasons for implementing an intake policy. The firm wants to be sure that it is not using its resources on work that is either less interesting or less profitable than other work that it might be able to obtain. There are also various reasons to implement assignment policies, such as to increase the productivity of a firm by using people and human capital more efficiently, or controlling the fairness of the distribution of the workload. Assignments are formally organized for partners, but especially for associates, through the ATC, also called the associate committee.

Assignment procedures are match-making and match-breaking procedures. In general, a file (a case) is handled by at least two lawyers, one partner and one associate. Sources and types of assignments vary: lawyers may spend time on assignments received directly from clients, on assignments received through a formal assignment system, and on 'spot assignments' (no continuing involvement in the matter). A partner must be matched with one or more associates (possibly with other partners too) to work on a file; then, once the case is closed, the task force is broken down and another is put together to work on another file. Official ATC procedure is based on the traditional view about training in the legal profession: associates should be trained mostly on the job, informally, and followed by a 'mentor'. Following this philosophy of apprenticeship, partners analyse and break down a complex problem into several parts, and attribute to each associate working with them and observing this exercise a small part of the tasks to be performed. Therefore, the ATC basic assignment principle is that associates should circulate and work with as many partners as possible, so as to be exposed to the greatest possible diversity of styles in the practice of law. ${ }^{3}$

However, intake and assignment procedures are always somewhat flexible (Lazega, 1993). Flexibility, at least in the implementation of one of the two steps, seems to be imperative because workflow depends on the nature of the practice. In some areas, clients usually come directly to the lawyer. In others, lawyers may work on files because they were given these files when they were associates and they stayed on these files. The firm is well established and corporate clients are passed down from partner to partner over the years. Clients come to partners through referrals from other lawyers in the community or through cross-selling by partners from another area of practice. According to SG\&R's intake procedure, new clients should be cleared with the managing partner, but this requirement is not systematically respected. Some partners do not even seem to know about it. Others acknowledge that they have problems saying 'no' to people. Clients whose work has been turned away may not call again. Partners take in the work, knowing that some colleagues are cooperative and will help with the workload. They are interested in the best associates, who are close and easily accessible, and know as much as possible about the issue. Some get used to specific associates with whom they like to brainstorm, and ATC choices may not always respond to such selection criteria.

Flexibility means that assignments are also often distributed by the partners who bring in the client. This is the informal 'patronage system', or clientelistic procedure: partners and associates choose one another based on more strategic ${ }^{4}$ and reputationbased criteria (Raub and Weesie, 1990). The main preoccupations of time-keeping members (obtaining a continuous flow of good work from clients or from (other) partners, and obtaining cooperation from colleagues to perform this work) are also solved by patronage. Partners have some leeway in choosing co-workers and in building up temporary task forces, i.e. choosing one another and associates to work on a case. Given the fact that interdependence among attorneys working together on a file may be strong for a few weeks, and then weak for months; given the flexibility needed to accommodate clients' needs; given the size and complexity of some files, a reliable co-worker is a highly valued resource for individual attorneys. In this situation, members' interest, as perceived by them, is in building strong ties to selected others. Such strong work ties, members think, should be a better guarantee for goodwill and cooperation than weaker work ties. Strong work ties are perceived to be an insurance policy against absence of (good) work and/or absence of manpower. They mean more than short-term security. They mean that efforts will be actually shared (i.e. everyone will pull their weight), and that one's own work will be recognized (i.e. colleagues will not grab all 
the credit for themselves in successful cases). For associates, for instance, they can mean access to partnership. Finders and grinders need each other. It makes sense for attorneys in need of (good) work to build strong, secure, and durable work relationships with such rewarding partners, who in turn need reliable peers and associates to carry out the actual work.

Some partners, especially the finders, ${ }^{5}$ are so used to assigning work themselves (without resorting to the ATC) that they often complain about problems especially in this multi-city firm - with identifying partners and associates with the right expertise, and with putting together the right task force to work on a case. Finders often express disagreement with the firm's minders as to whether or not the formal assignment mechanism works efficiently. ${ }^{6}$

Associates sometimes also express their dependence and distrust of the assignment committee. As already mentioned, their main interest is in becoming partner. They know that they are expected to bill at least 1800 hours a year, or to gross four times what they earn as a salary. Under this kind of pressure, a regular flow of good work is most welcome, but they are in a bind about how to get this work. ATC members - sometimes called the 'schedulers' - can provide this work, and they also evaluate associates twice a year: associates have to listen to them and abide by their rule. However, if they follow the schedulers systematically, they can often get stuck with assignments from which they will not learn enough, or with a partner who will not introduce them to other partners, thus reducing their chances in the internal labour market. Associate loyalty to the ATC is good for insurance, but not so good for learning and social capital. Many want the best work from the best clients, not run-of-themill work from the scheduler. The scheduler can provide diversity and access to many partners. But the more successful associates are, the more they become strategic, the more they tend to avoid the scheduler and try to manage their career in a more 'intrapreneurial' way. They end up saying 'yes' to partners who can sometimes guarantee years of good work (in which they learn something) for good clients, instead of turning them down and seeking the schedulers' approval. Of course, the minders might step in, but then associates count on their patron to solve the problem.

\section{Patronage and the Threat of Defection}

Although the coexistence of welfare and patronage is not a mystery to anybody in the firm, choice of patronage is a problem for firm integration. In some ways, finders and minders do have different interests. Both forms of status are indispensable to the running of the organization, but clientelism does represent a danger of defection. Fieldwork provided enough unobtrusive and circumstantial evidence that this is a serious concern. As in any professional services firm, partners do perceive the creation of stable workgroups as a threat of opportunistic behaviour. ${ }^{8}$ Lawyers who do not commingle their assets can take away with them a large volume of business, and continue to handle that business somewhere else.

In effect, the clientelistic exchange system, and its underlying social discipline, represent a 'neat kind of social plumbing' (White, 1985, cited by Flap, 1990). But it also allows individual members to team up, to build strong, presumably repeated, more secure and reliable work relationships with others, partners or associates, who will also pull their weight, recognize one's contribution, and share credit and responsibility among themselves. The fact that the ATC committee is considering the possibility of their colleagues' defection when matching partners and associates is not official policy. It was never said explicitly that the role of the ATC committee was to prevent defection. This raises the issue of how the two systems coexist while still preventing finders from defecting. From this perspective, it is part of 'welfare' to keep the finders in check. This means that the minders must try to prevent finders' workgroups from stabilizing and growing sufficiently to be in a position to defect easily from the firm.

Providing evidence for minders' capacity to control finders (by controlling enough manpower to prevent defection) is not easy. Information is lacking about each member's choice of source of work (welfare or patronage) for all the cases during the year, and about what the structure of assignments would look like if work were allocated exclusively by some sort of internal market and reputation mechanism, i.e. if the clientelistic match-making process were undisturbed by ATC schedulers. Nor do we know what would happen if the official ATC matchmaking process were undisturbed by 
patronage interference. Disentangling quantitatively the effect of each system (welfare and patronage) on the actual allocation of work would require data on work allocated by ATC during the previous year and a comparison with the actual log of all work performed by all members during that year. A comparison between the two would provide an understanding of the relative influence of each system. ${ }^{9}$ But precise and systematic information was not available about the number of hours actually worked by each associate for each partner, and about options before ATC members and their colleagues when the matches take place.

Therefore, in the next sections, indirect quantitative evidence is used instead to show that the firm has found a mechanism to prevent disintegration of the organization by creating a balance between the two systems. Analysis of network data about who considers whom to be a strong and reliable coworker is used to address this issue. The analysis looks first at the logic of members' choices of strong co-workers, i.e. at how they build long-term work ties - a characteristic of clientelistic solidarity. It shows that the way in which members find strong cooperation is by seeking niches. Second, the result of such strategies at the structural level is examined by looking at the pattern created by the aggregation of these choices. This pattern provides indirect evidence for the existence of a Montesquieu mechanism preventing easy defection by partners with market clout. Interests analysis at the individual level is followed by network analysis at the dyadic level, then by the consequences of members' logic at the structural level.

\section{Niches and the Social Construction of Strong Work Ties ${ }^{10}$}

Choosing co-workers in this collegial context is a delicate operation. Associates compete for the attention of partners. Partners compete for the best associates and for prestige within and outside the firm. How do they recognize each other as strong co-workers and what is the result of these selection processes? Two statements can answer this question. First, choices of strong co-workers are subject to constraints from selected dimensions of firm formal structure; they are thus socially constructed. Second, under such constraints, choices tend to build stable workgroups of attorneys specialized in the same area and able to defect from the firm and establish themselves as specialized 'boutiques'. Network data on strong work ties collected in the firm confirm these points. Members' connections with strong co-workers (as opposed to colleagues with whom one collaborates more superficially) were reconstituted by asking all the lawyers in the firm to answer the following question:

Here is the list of all the attorneys in the firm. Because most firms are also organized very informally, it is difficult to get a clear idea of how the members really work together. Think back over the past year, consider all the people in your firm. Would you go through this list and check the names of those with whom you have spent time on work matters. By 'working with' I mean that you have really spent time together on at least one case, that you have been assigned to the same case, that they read your work product and that you have read theirs; this includes professional work done within the firm like Bar association work, administration, etc. ${ }^{11}$

In this context, such ties can be considered to be strong work ties that are built on common experience of previously working together. They reflect the existence of goodwill from colleagues prepared to help and cooperate. They allow members to anticipate further transfers and exchanges of this resource. ${ }^{12}$ In effect, analysis of the determinants of these sociometric choices carried out at the dyadic level can be expected to show that choices of strong co-workers are influenced by formal dimensions of firm structure such as office membership, specialty, and hierarchical status. A statistical method particularly well designed for that purpose, the so-called $p_{2}$ model (Van Duijn, 1995; Van Duijn and Snijders, forthcoming; Lazega and Van Duijn, 1997), is used for that purpose. ${ }^{13}$ Specifically, in their struggle for access to cooperation (work opportunities or manpower), it should be easier for members to obtain it on a day-to-day basis in the same office, and it should be more likely that members of the same office will expect long-term solidarity from one another (as opposed to expecting strong cooperative goodwill from members of other offices). Given that they often work together on the same files, it should also be more likely that members of the same specialty 
will expect long-term solidarity from one another (as opposed to members from other specialties). It should also be more likely that members of the same hierarchical status will rely on each other for strong cooperation and expect long-term solidarity from one another (as opposed to expecting strong cooperative goodwill from members of different hierarchical status): for example, junior partners often have clientelistic ties with senior ones; in addition, partners know that associates may not be there for long.

For associates, the picture is different, but with the same effect: they may want to expect strong cooperation (to obtain sufficient quantities of interesting work, for example) from partners, but they know that partners call the shots, that all partners interests' are not the same (for example that the schedulers try not to let clientelistic ties get in the way of 'fairness' in access to such cooperation). Therefore, they may fall back on other associates in spite of efforts by partners to desolidarize associates. Finally, I would argue that among business heads more exogenous attributes such as gender are not likely to have an effect on the extent to which members will rely on each other for strong cooperation. Solidarity based on having been to the same law school (i.e. having the same (lack of) prestige) should also be unlikely to have an effect on the choices of strong co-workers, the latter being too closely associated with business decisions. ${ }^{14}$

The analysis below shows that members find it mainly among colleagues in the same office and from the same specialty. In fact, they tend to find this and other resources in niches constructed by members based on similarities along dimensions of formal structure.

\section{Independent Variables}

These hypotheses were tested by using as independent variables three dimensions of the structure of this firm which are expected to have an influence on access to sources of resources: seniority and hierarchical status, office, and specialty; and two more exogenous or personal attributes, gender, and law school attended. Table 1 presents the distribution of lawyers in this firm according to these variables.
Table 1. Distribution of members per variable

\begin{tabular}{lrcc} 
Status & Partners & Associates & N \\
$\ldots \ldots \ldots \ldots \ldots \ldots \ldots \ldots \ldots \ldots \ldots \ldots \ldots$ & \\
Seniority level 1 & 14 & 7 & \\
Seniority level 2 & 13 & 10 & \\
Seniority level 3 & 9 & 5 & \\
Seniority level 4 & & 7 & \\
Seniority level 5 & & 6 & \\
Office I & 22 & 26 & 48 \\
Office II & 13 & 6 & 19 \\
Office III & 1 & 3 & 4 \\
Specialty litigation & 20 & 21 & 41 \\
Specialty corporate & 16 & 14 & 30 \\
Men & 33 & 20 & 53 \\
Women & 3 & 15 & 18 \\
Lawschool Ivy League & 12 & 3 & 15 \\
Lawschool New England & 11 & 17 & 28 \\
$\quad$ non-Ivy League & & & \\
Lawschool other & 13 & 15 & 28 \\
N & 36 & 35 & 71 \\
\hline
\end{tabular}

The first covariate is hierarchical status, a variable with two levels - partners and associates - where the reference category, i.e. the category of the explanatory variable with regard to which differences are measured, is associate. This variable is elaborated upon in the second and third covariate. The second covariate is a variable with three levels, indicating the three possible levels of seniority for a partner. This variable is transformed into two dummy variables, indicating the first and second level of seniority, respectively, 'seniority level 1', and 'seniority level 2'. The third covariate is related to the seniority of associates, taking the values 1 through 5 . For associates, seniority has the meaning of being a member of a cohort recruited the same year. The main difference here will be between being at the same level of seniority vs. different levels (same seniority level vs. not). We can thus look at the gradual effects of numerical rank on the choices of sources of resources. All these actor attributes concern the formal position of the lawyers within the firm. Nine dyadic attributes were deduced, which either express the similarity of these positions or their dissimilarity in terms of superiority.

The next set of covariates reflect other actor attributes and derived similarities. The fourth covariate is office, a variable with three levels, 
Office I, II, and III, where the reference category is Office I. From this variable two dummy variables are derived - Office 2 and Office 3. The fifth covariate is specialty, a variable with two levels - litigation and corporate - where the reference category is litigation. The sixth covariate is gender, where the reference category is men. It should be remembered, however, that most women in the firm are associates. The seventh covariate is law school attended, a variable with three levels. From this variable again two dummy variables are derived - Law school 1, indicating whether or not a lawyer went to an Ivy League university, and Law school 2, indicating whether or not a lawyer went to a New England non-Ivy League university; the reference category is Other university. The last two variables are introduced in the model to look at the extent to which attributes of actors defined outside the firm are used in a discriminatory way within the firm in constructing access to work. From these attribute variables, similarity variables were also constructed. ${ }^{15}$

\section{Results}

Using these covariates, several models were estimated to establish the influence of such dimensions of structure on members' choices of co-workers.
Table 2 presents the best model provided by this analysis. ${ }^{16}$ The parameter estimates of $\mu, \rho$, etc., are given together with their standard errors. Including other effects did not improve the model.

The underlying story behind these figures can be summarized as follows. First, in this firm, at the overall level, differences in hierarchical status, office, specialty, gender, and law school do not have a significant effect on the propensity to choose strong co-workers. Members of one office do not cite more or fewer strong co-workers than members of another office, members of one specialty more or fewer than members of another, women more or fewer than men. In general, partners do not choose more or fewer co-workers than associates, but one sender effect is significant, i.e. that senior partners tend to cite less strong co-workers than other lawyers.

Second, office, specialty, gender, and law school do not have a significant effect on the fact of being sought out as a strong co-worker. Members of one office are not significantly sought out more or less than members of another office, members of one specialty than members of another, women than men. There is one significant receiver effect, however: it shows that the more junior the associates, the less they are cited as strong co-workers. This shows that, in this firm, the choice of co-workers

Table 2. $p_{2}$ estimates of attorneys'choices in strong co-worker's network (standard errors in brackets)

\begin{tabular}{|c|c|c|c|}
\hline & Parameter & Empty Model & Final Model \\
\hline \multirow[t]{4}{*}{ Sender } & Variance $\sigma_{\mathrm{A}}^{2}$ & $0.89(0.12)$ & $0.87(0.12)$ \\
\hline & Status & & $0.41(0.34)$ \\
\hline & Partner seniority level 1 & & $-0.80(0.38)$ \\
\hline & Partner seniority level 2 & & $0.34(0.38)$ \\
\hline \multirow[t]{2}{*}{ Receiver } & Variance $\sigma_{B}^{2}$ & $0.48(0.07)$ & $0.41(0.06)$ \\
\hline & Associate Seniority Level & & $-0.19(0.05)$ \\
\hline Sender-receiver & Covariance $\sigma_{A B}$ & $-0.44(0.08)$ & $-0.31(0.07)$ \\
\hline \multirow[t]{7}{*}{ Density } & $\mu$ & $-2.34(0.10)$ & $-3.81(0.22)$ \\
\hline & Similarity status & & $0.65(0.15)$ \\
\hline & Similarity office & & $1.03(0.13)$ \\
\hline & Similarity office 2 & & $0.85(0.23)$ \\
\hline & Similarity office 3 & & $0.35(0.61)$ \\
\hline & Similarity specialty & & $1.41(0.10)$ \\
\hline & Similarity status*specialty & & $-0.55(0.14)$ \\
\hline \multirow[t]{2}{*}{ Reciprocity } & $\rho$ & $3.16(0.12)$ & $3.16(0.20)$ \\
\hline & Similarity status & & $-1.03(0.26)$ \\
\hline
\end{tabular}


is slightly asymmetric because it is sensitive to hierarchical status, as represented by seniority levels: senior partners and junior associates, i.e. both extremes, behave differently than the rest of the members.

Third, various similarities account for many of the differences observed in the choices of strong co-workers. Density effects show that the general activity in this network tends to be significantly higher among attorneys similar in terms of various characteristics. Members tend to choose as strong co-workers lawyers of the same specialty more than in different specialties (strongest effect), in the same office (especially in office 2), and of the same hierarchical status. Members similar in term of both hierarchical status and specialty tend to cite each other as strong co-workers less often than members different in terms of both hierarchical status and specialty (perhaps because when they cite members of other specialties, they tend to choose people below them when they are partners and above them when they are associates).

Finally, these similarities do not account much for direct reciprocity among members. A single extra direct reciprocity effect is significant: attorneys similar in hierarchical status reciprocate their choices of strong co-workers more ${ }^{17}$ to each other than attorneys different in hierarchical status.

Expectations formulated above are thus confirmed. Access to strong work relationships does depend on niche membership and formal attributes. Mostly, the overall density effects show that general activity in the co-workers' network tends to be significantly higher among attorneys similar in terms of formal characteristics than among attorneys different in terms of those characteristics. Among these similarity effects, the strongest are office, specialty, and hierarchical status in decreasing order. Mobilizing similarities in terms of several attributes is indeed perceived by members to be a useful device for creating strong work ties. This tends to happen with colleagues in the same office, in the same specialty, and - more weakly - of the same status. When controlling for such effects, more personal or exogenous characteristics of members become insignificant for access to work-related goodwill. They do not have a significant influence on members' citations. Attributes such as gender do not contribute significantly to shaping strong work ties when controlling for more work-related attributes. Actors tend, to some extent, to rely on homophily based on endogenous characteristics, i.e. defined from within the firm. ${ }^{18}$ By bowing to structural constraints, members do tend to create, in their local office, specialized niches nested within the general practice firm, with same or different status colleagues. This confirms that members build durable, i.e. long-term, exchange relationships by looking for contexts in which such ties provide resources on a generalized exchange basis (Lazega and Pattison, 1999).

This logic of individual action helps understand the coexistence of welfare and clientelism in this organization. In effect, I argue that niche-seeking structures the organization in a way that is likely to help minders in their efforts to control finders and their threat of opportunistic defection. Specifically, office and specialty boundaries make it easier for minders to control access to well-identified pools of manpower, and thus to prevent the emergence of enough direct clientelistic ties within any team surrounding a well-identified finder potentially seeking easy defection. To show this, it is necessary to use other methods of analysis, where the individual remains the unit of analysis, and where transfers and exchanges of collaboration in the firm are made visible. In the next section, SG\&R's transfer and exchange system (for this resource) is described in a reduced form by an analysis of the same co-workers' network in terms of structural equivalence. ${ }^{19}$ This establishes a partial order which helps account for a 'political' integration of the firm. Within the structural constraints reflected by niche-seeking, a process goes on that helps minders to prevent finders from teaming up and out with more grinders.

\section{RED-Sets out of Niches? A Montesquieu Structure}

Analysis of the network of strong work ties ${ }^{20}$ shows that, at the time, the transfers and exchange system (for this resource) in this firm is made up of ten different sets of approximately structurally equivalent actors. Figure 1 represents these sets, their members, and the relationships between the sets. It is based on 


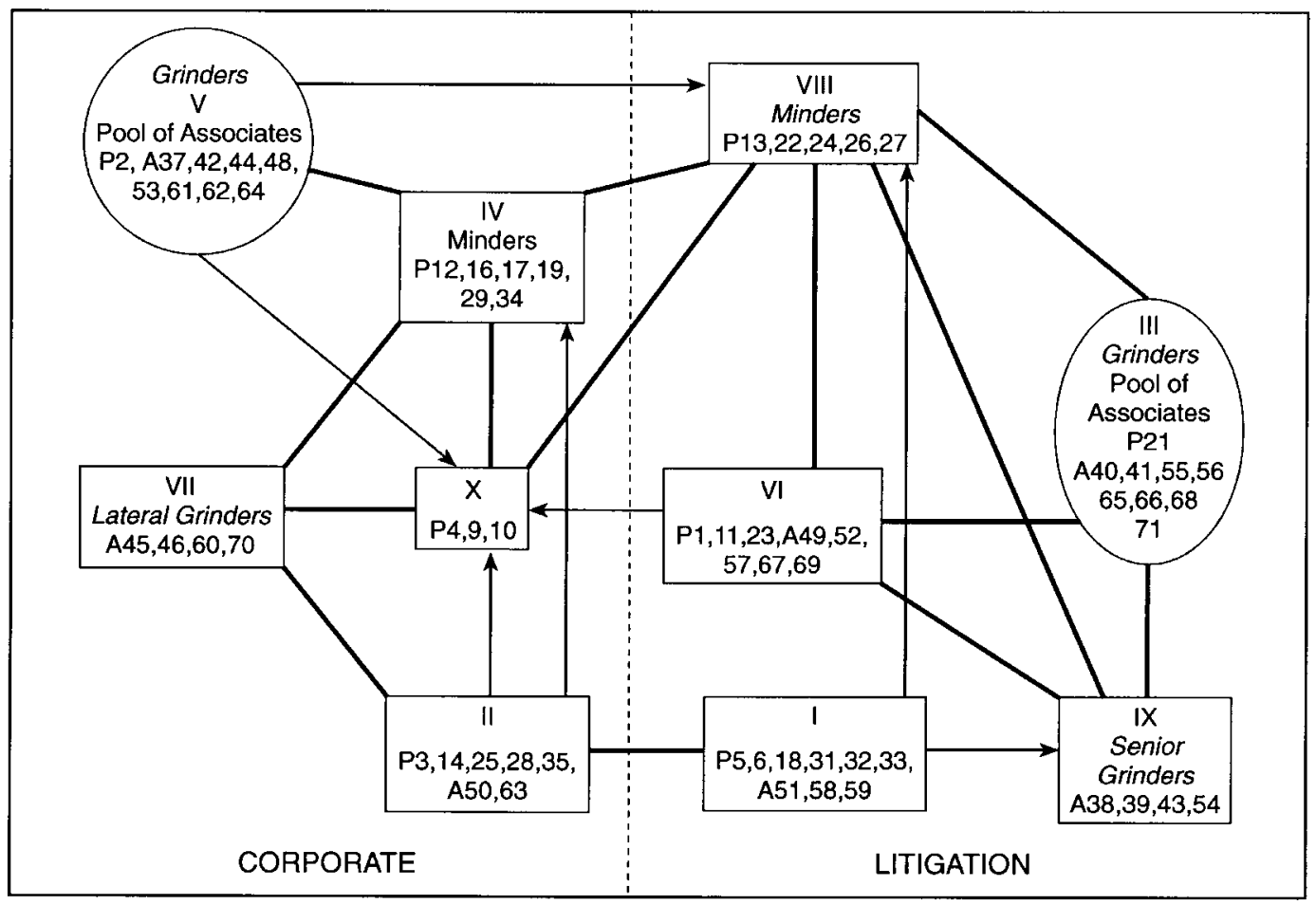

Figure 1. Relationships between positions of approximately structurally equivalent actors in the strong co-workers' network. Thick arrows indicate mutual ties. For detailed description of positions and their members, see the Appendix

the density table presented in the Appendix, along with a detailed description of Figure 1.

Members of each set, or position, are partners and/or associates occupying an approximately similar position in the structure of strong work ties; they have approximately the same relational profile, approximately similar work ties with firm members outside this position, and often have strong ties within the position too. Two persons in the same position do not necessarily work together, but they work together with others in more or less similar patterns. The configuration describes the system of interdependencies that is explained by the nature of legal work, by members' common niche-seeking strategies, by power relations among members, and by the ways in which the finder-minder relationship plays itself out in the two different specialties. The method helps detect subsets which may be able to team up permanently (alone or with others), and create - within their niche - stable workgroups bringing together finders with direct access to their own associates.
A first split ${ }^{21}$ reflects the strong influence of specialty within the firm. On the left of Figure 1, corporate lawyers, on the right, litigators. Each specialty - particularly litigation during the early 1990s - could indeed leave the firm and create a firm of its own. But none could be certain that the market could bear it; 'boutiques' of that size need a highly concentrated market such as that of New York City. The next split shows that defection threats could presumably exist for all these specialized positions including partners, i.e. Positions One, Two, Four, Six, Eight, and Ten. An actual breakaway threat exists particularly for Position One, and is lower for the other positions. Some of the reasons for which firm integration is nonetheless maintained in this situation are outlined below.

I qualify as 'Ready-for-Easy-Defection' (RED for short) a subset or a position that has three characteristics. First, it has a high enough average income, which represents its capacity to be immediately in business' outside the firm, and thus the kind of revenue that compares with the income achieved at 
SG\&R. ${ }^{22}$ Second, it is a stable team with high cohesion (i.e. strong work relationships among its members) and sufficient size to be immediately operational outside the firm. High density within a position can be read from the density table in the Appendix. To this form of economic and social capital (clients and reliable workforce), I will add a third condition, i.e. that its individual members must not have a lifelong investment in the firm as a whole; such an investment in economic and social capital - with the compensation system rewarding loyalty with the highest incomes - can only pay off if one stays within the firm (Frank, 1985). This means that positions with finders in them (such as Ten and Six) do not necessarily qualify for RED status. In effect, such finders, especially if they are very senior in that firm, have too strong an incentive to stay. They also may not include good associates willing to follow them elsewhere. Remember that associates are very strategic about whom they want to work with, and being too close to a single rainmaker may sometimes be counter-effective in terms of career.

When reviewing partners' positions in Figure 1 to check for these criteria, none has RED status. Position One comes closest to RED status. It includes six partners and three associates, all Office II litigators. The position has the second rank for economic importance in the firm (Partners 5 and 18 are among the top economic performers), and it is a stable and cohesive team with hard-working associates. However, it has low average centralities in the firm's co-workers' and advice networks ${ }^{23}$ for that year, and, in spite of the presence of Partner 32 - who represents the ATC committee in Office II - it is not large enough (for large and urgent cases) to be immediately operational outside the firm (too high a ratio of partners to associates). In effect, it would need more associate manpower, but cannot obtain direct access to the pool of litigation associates (Position Three) or lure away Position Nine senior associates, who have too strong an investment in Positions Six and Eight. In particular, Positions Eight and Nine would get in the way of Position One's attempts at reaching position Three, and control access to that workforce. Finally, although two of its members are senior enough to receive very high compensation, this rent does not include all the returns for lifelong investment in firm social capital, especially with Position Two.
Position Two does not come close to RED status. It includes five partners and two associates on the Office II corporate side. The position is a cohesive team and most of its members do not have lifelong investment in firm social capital (for example, Partner 3 is a former CEO of a large insurance company who only recently joined the firm; Partner 14 is a former managing partner hired laterally from another firm). However, it ranks only fourth (out of six) in economic importance in the firm (Partner 14 is its only top financial performer for that year). In addition to this average economic performance, it has low average centralities in the firm's co-workers' and advice networks for that year, and is not large enough to be immediately operational outside the firm. It would also need more manpower, but cannot gain direct access to the pool of corporate associates of Position Five. Position Four gets in the way and controls access to that workforce.

Position Six does not come close to RED status either. In contrast to the two previous subsets, it does have direct access to a reserve of manpower in the pool of associates. But it is a weakly cohesive (in the co-workers' network) Office I position and, in spite of including highly prominent and top performing Partner 1, grosses a relatively low average amount of fees (it ranks fifth in that respect). Its members do work closely with Positions Eight and Nine, but it is difficult to conceive of this subset as defecting without Partner 1 being at the origin of that move. For economic, social, and historical reasons, however, it is also difficult to conceive of him leaving. He derives too much of his social status as 'the Monarch' from speaking on behalf of the firm and representing its sense of professionalism.

Position Ten comes closer to RED status than Positon Six. It is indeed a powerhouse: it is the highest grossing position in the firm for that year, mainly thanks to Partner 4's performance, and it has high average centrality in the co-workers' network. However, many issues prevent its defection. Its three partners rely very little on one another for work, and their subset is not a cohesive team. The position would not defect without the leadership of Partner 4, who has access to large clients and provides many colleagues with work; but - as for Partner 1 - he is at the top of his firm, with one of the highest incomes, a lifelong investment in the firm and its members. The three are simply so senior that they 
would not bother leaving. Finally, it would be hard pressed to grow in size sufficiently quickly: the pool of associates on the corporate side (Position Five) is 'shielded' from these powerful partners by Position Four partners.

Finally, Positions Four and Eight are in special situations. Position Four could come close to RED status. It includes six Office I corporate partners, among whom Partners 12, 17, and 19 are top performers. Partners 16, 17, 19, 29, and 34 are also highly central due to their ties with associates. It grosses an average amount of fees and has a high average centrality in both task-related networks. However, it is a cohesive position because members cooperate on firm management tasks - not so much on large cases. It concentrates administrative authority, but may not yet have enough of its own clientele. It does not include associates systematically because corporate work often does not mobilize as much manpower for long periods of time as litigation work does. It has direct access to Position Five and Seven workforce, but as much in its members' capacity as ATC officials as because of their rainmaking power.

The situation is somewhat different for Position Eight. It would not be able to defect easily. It includes Office I partners, mainly litigators, who are recognized as truly good citizens by other partners. They are in charge of the welfare system for associates on the litigation side, and do not seem to groom their own clients. It is the lowest performing group of partners in economic terms (in spite of the presence of top performers Partners 13 and 26). It has the highest average centrality scores in the two taskrelated networks, but this is due to its ATC scheduling responsibilities rather than its rainmaking capacity. It has direct access to Position Three and Nine manpower, but again as minders.

Notice that, by trying to be strategic in their choices of partners, associates ${ }^{24}$ may also play a role in preventing some partners' positions from reaching RED status. Senior associates in Positions Seven and Nine, for example, could help some partners' positions grow sufficiently quickly to be operational elsewhere without delay. But in order to increase their chances of making partner, they have learned to divide their loyalties between, and invest in ties with, many partners (here at least between two positions of partners); they may hesitate too much between losing an important broker position (for Position Nine) and helping defectors.

Thus, although many positions could defect, and seriously harm the business of the firm, the fact that not a single one of them has RED status means that it could not do this easily and advantageously for its senior members. Within the niches where they find easy access to resources needed to work and survive in the firm, members would find it difficult to create stable and RED subsets. The basic criteria for that purpose - high enough average income, sufficient size, the right type of social capital (high cohesion, manpower, and few lifelong investments in the firm as a whole) - make it more difficult to defect in such a context than is usually acknowledged. In particular, Positions One and Ten do not have systematic and direct access to pools of additional workforce and cannot grow rapidly enough to become serious threats. For that purpose, they would need to go through Positions Four and Eight, which are minders playing the welfare system in the ATC committee.

Patronage is particularly likely with Positions One, Two, and Ten. Welfare is mainly represented by Positions Four and Eight. In this light, the welfare system appears to have the function of a political device for prevention of stable RED workgroup development, and therefore prevention of firm disintegration. ATC function is indeed as much a match-breaking device as it is a match-making one. The logic of niche-seeking helps minders find a position in the structure that helps them prevent finders from building many strong work ties with grinders. Notice that policing by minders is not so expensive. This form of damage control by minders does not enforce the intake and assignment rules very actively or punish the non-compliant. It prevents the non-compliant from defecting.

With this pattern of strong work relationships, the firm provides a structural solution to a classical collective action problem, that of integration and prevention of defection. It remains one firm because the coexistence of the two intertwined solidarity systems, the welfare system and patronage, creates a specific and stable pattern of work relationships. I call this structure a Montesquieu structure (see also Kuty, 1998) because its main characteristic is the balance of powers between two types of strong statuses within this polycratic organization (minders 
and finders), each representing a different solidarity system. This balance imposes restrictions on the behavioural alternatives of actors, thus leading to political integration and foreclosing violent conflict in such an institutional context (Flap, 1988, 1990).

In many ways, the power that makes the Montesquieu structure itself survive (by keeping the welfare system in place) is the partnership as a whole. One could easily imagine that finders might 'infiltrate' the minders of the assignment committee; but the members of this committee are elected by the committee of the whole at partnership meetings, which operate under the one partner-one vote rule. One step removed, democracy among the partners is the reason for the coexistence of the two solidarity and control systems, for the maintenance of firm integration, and for durable work relationships.

\section{Conclusion}

This paper has identified a social mechanism of integration that helps collegial organizations, always in danger of unravelling, maintain durable cooperation and prevent defection, a form of opportunistic behaviour. The logic of members' niche-seeking behaviour is shown to help a welfare system keep a patronage system in check. A corporate law partnership provided a good setting to test the hypothesis that a structural solution, called a Montesquieu structure, can be found to this typical problem of collective action among peers. Interdependence is cultivated and protected by a political process (checks and balances backed up by democracy among partners); it is a basis for solidarity in this group. Thus a combined multi-level approach to rational choice and structural analysis helped to identify social mechanisms that facilitate solidarity and prevent specific forms of opportunistic behaviour. ${ }^{25}$ Paradoxically, structural analysis - which is often used in a static and descriptive perspective - provides an additional understanding of the durability of the organization.

This multi-level approach provides an understanding of the forms taken by members' interdependence and the partial order that it produces at the structural level. Cooperation in such collegial settings is shaped by the ways in which this organization structures itself and balances different sources of power, as much as by professional ideology (the idealization of work well done, unconditional allegiance to the law, and the priority of ethical considerations over business pressures). Durable relations are made possible in a collegial organization by a division of powers within an oligarchy - to use Michels's (1915) term. This oligarchy is divided, and it is precisely this division which provides a structural solution to the collective action problem of maintaining durable work relations among peers in a relatively flat and knowledge-intensive organization.

The generalization of a mechanism observed in a law partnership remains to be verified. Other types of knowledge-intensive or professional work are sometimes organized in this way, for example in banking (Eccles and Crane, 1988), in industrial design (Sutton and Hargadon, 1996), or in accounting and consulting (Morrill, 1995). However it remains to be seen whether different types of collegial organizations - for example with different sanctioning capacity, especially for partners who do not respect assignment rules - have this type of Montesquieu solution to problems of integration and durable cooperation. In that respect, much remains to be done.

\section{Notes}

1. The beginning of the 1990 s was a period of economic downturn in the Northeast: levels of future demand were not easily predictable.

2. This is not the real name of the firm.

3. Here is what a minder in charge of the ATC on the litigation side has to say about this: 'I have to make sure that people are busy doing the right things, taking on the right case. When a matter comes in, that issue of who is going to be assigned the case is a very important issue for most law firms and certainly has been for us, and we've had an increasingly sophisticated process for doing that. Fifteen years ago it was absolutely accepted by every lawyer in the firm that if a client called you up and said would you handle this case, you could handle it. It was yours. Nobody would ever challenge that. That is no longer true. Now no matter who you are in the firm, if somebody calls you up and says will you handle this case, that lawyer does not have the authority to take the case on his own. He should run it through an intake 
procedure, and I along with the other section, or along with our managing partner, we may talk about whether or not the lawyer who originated that case ought to get to handle it. And in fact some of the biggest and really the only fights we ever really had have involved that issue where a very large case with a lot of publicity came into the office to a particular lawyer and we concluded that he shouldn't handle it. That he was not the best lawyer for the case. And we said it's going to another lawyer. And that lawyer didn't like it and took it to the managing partner, and to the partnership meeting, and we had a lot of discussion about it. And the decision we made stood. And we established a fairly important precedent that our intake system was going to decide who's going to get the case and who's going to do the work. Most of the time it's not a problem. Most of the time the lawyer who originates the business is perfectly appropriate to do it. Sometimes also a lawyer will originate business, he'll get a call from someone, and he won't want to do it. Then in the process of intaking it through me he'll say to me can you find someone to do this? That's also something that I will do. I'll assign it to somebody.' (Partner 13).

4. In Blau's (1964: 21-2) and Flap's (1990) more general terms, members of an organization have four possible alternatives to becoming someone's client (in a patronage system), i.e. to be deferential and promising future services in return: immediate reciprocation with a service that the patron immediately needs; securing the needed service elsewhere, with another patron; coercing the other into providing the service; or doing without the service. Associates in a law firm can try the first and second solutions, but with difficulty: the original situation being one of unequal access to diverse resources, and also because the number of patrons is limited. Strong opposition from one of them would ruin one's chances of becoming a partner. But they cannot use the last two alternatives: clients compete for special treatment, and there is always another potential client willing to take the place of an unwilling one (Flap, 1990). Therefore, clientage is the only secure option, apart from the welfare system of the ATC. Associates need a champion, and no enemies (Burt, 1992). In the case of $S G \& R$, there is more than one partner, and associates could align with other partners, using a factional structure (Lazega, 1992, 1995b). But they cannot do this too often without sinking costs and building a reputation of instability; and it would not improve their prospects given the number of other clients, the scarcity of the ultimate reward, and the limit defined by patrons to their own competition.

5. Finders were identified as partners who are top performers, central in the co-workers' networks, and reputed in the firm to be close to large identifiable clients. Minders were identified as partners with important administrative responsibilities (they usually do not overlap with the finders). All the others are considered grinders.

6. Partner 6 formulates this clearly: 'I don't think of my clients as my clients in an economic sense; but I think of them as my clients in a personal way. The people I am doing work for, that I have a personal relationship with, that I know as friends or whatever. It would be foolish for a firm to ignore that relationship ... [This is why] the ATC committee does not really work very well. Associates do generally get work directly from their partners. When I noticed that a lot of my partners didn't use the associate committee I stopped doing it too. The result is the same, but we don't necessarily go through the committee.'

7. As an example, Associate 37 considers that there is a tacit contract between himself and Partner 15, his obvious patron. His dependence on Partner 15, and his distrust of the assignment committee come across clearly in his interview: 'Any partner wants to have his associates next door, to be able to go down the hall and talk to them about their files. I have been here for five years and it's been that way from day one. I have heard partners say, year after year, "we need to get Associate 37 to work with partners from other offices", and it doesn't happen. For example, I had an associate review last August. One of the things which was said was that the corporate ATC indicated that they wanted me to work with other partners, and they made a commitment to do that. During the five months since then, I worked with only one new partner. It takes time, a concerted disciplined effort to see that I get that kind of work, to make sure that all partners are advised that it is worthwhile to work with me [Associate 37]. Alan [Partner 15] is quite supportive, and he would never do anything against my working with others, but he leaves it to me. That's a touchy issue. And I have probably not taken enough initiative in the past. Because of the way the firm is structured [ATC committees], I cannot pick up the phone and call partners one by one and ask them if they have work for me. I have to go through the ATC committee. My hesitation in the past is that I didn't want to annoy them, to pester them, to bug them, and also to annoy Alan. But after the review I realized that I couldn't afford any more lip service. I have decided to call up the ATC and ask "which new 
partner do you want me to work with this week?" The firm did not help me acquire a specialty which makes me indispensable. I received assignments from Alan, I assisted him on his files, and then the clients began to call me directly, and I became their primary contact. Work for Alan and work for these clients represents most of my work. Whether this will help next year with the partnership decision, I don't really know'.

8. One partner discusses this form of 'opportunistic' behaviour in explicit terms as a natural preoccupation in private professional services firms: 'There are client loyalties to individual lawyers within the firm; but among ourselves we view all clients as clients of the firm. And indeed if you are an individual to whom the client has demonstrated a great degree of loyalty, one of your responsibilities is to make sure that there are other partners to whom that client may also look and rely upon. Not necessarily on an ongoing basis. But if for some reason, for example if I am away, if I were suddenly to decide to go pump gas for the rest of my life, any number of things, that client loyalty is not an asset that belongs to me. If I were to go to another firm, if I have done my job well here at $S, G \& R$, if I call my client and say I want you to know that I am in firm X,Y\&Z now, that client's response should be Whom at $S, G \& R$ should I call now?; it shouldn't be What's your new number?. Whether that would be the case in all cases, who knows; that's what ideally it should be'.

9. ATC $\log$ simply does not exist: its existence would allow the members of the firm to have a closer look at the two allocation procedures. This would probably create opportunities for confrontation between the two systems and, indirectly, between the minders and finders representing them. This is not the solution adopted by the firm, which opted rather for a mechanism establishing a balance of power between the two, not a confrontation.

10. I am grateful to Marijtje van Duijn for help and advice with the data analysis based on the $\mathrm{p}_{2}$ model. For a detailed description of this method, see Van Duijn and Snijders (1996) and Lazega and Van Duijn (1997).

11. This particular name generator (having spent time on work matters) elicits strong work ties because it eliminates short spot assignments that do not reflect the existence of a real commitment to working with one's colleague.

12. There are various ways in which a tie can be considered to be 'clientelistic'. Pitt-Rivers (1954) requires 'lopsided friendship' for the existence of such a relationship. In the case of this firm, this is too strong a requirement. The conditions retained here are the systematic selection of others as strong and reliable co-workers (in a context where the rule is not to select them oneself), and differences in terms of formal status (partner-associate), informal status (findergrinder), and seniority (senior partner-junior partner) between the members selecting each other. Elsewhere, the interlocking of co-workers' and friendship ties in this firm is shown to be very weak (Lazega and Pattison, 1999). In general partners have clientelistic ties with lower status members with very few friendship ties expressed, even asymmetric ones; lower status members are kept at arm's length and do not have to express friendship for their patrons.

13. In this method, the unit of analysis or dependent variable is the binary relationship from one actor to the other. The dependency between the two relationships constituting a dyad, as well as the interdependence between relationships from and to one actor, are taken into consideration. The explanatory (independent) variables are actor and dyad characteristics, related to or derived from actors' formal positions and other relative characteristics. This method is the most adequate in this case because the dyad independence assumption is not plausible; it is relaxed in the $\mathrm{p}_{2}$ model by incorporating random parameters for each actor with an appropriate covariance structure, representing the interdependence between relationships from and to the same actor.

14. This does not mean that solidarity of another kind does not exist among members sharing this type of characteristic.

15. The similarity variables used in Table 2 are (in increasing refinement) similarity in status, taking value 1 if both actors in the dyad are partners or if they are both associates; partner similarity, 1 if they are both partners; seniority 1 similarity, 1 if they are both partners with seniority 1 ; seniority 2 similarity, 1 if they are both partners with seniority 2; associate similarity, 1 if they are both associates with the same level of seniority. The first constructed and most general superiority variable is superiority, which takes value 1 if the relation is directed from $i$ to $j$ and $i$ has a lower level of seniority than $j$; it takes value -1 if the relation is directed from $j$ to $i$ and $i$ has a lower level of seniority than $j$. A similar definition is given to partner superiority, where $i$ and $j$ both have to be partners, for associate superiority where $i$ and $j$ both have to be associates, and for 'partner-associate superiority', where $i$ is associate and $j$ is partner. It is important to realize that not all of these covariates can be used at the same time, because of dependency between them. For instance when only 
status is used to distinguish formal positions of partners, then status similarity or partner similarity and superiority or 'partner-associate superiority' can be used for the modelling of the density parameter.

16. A forward selection procedure was used to reach the best model presented in Table 2. For a detailed description of the model selection procedure, see Lazega and Van Duijn (1997). The variance components and the general density parameter $\mu$ and reciprocity parameter $\rho$ are part of the model. In this network, few sender or receiver or extra-reciprocity effects are significant; the variance parameters for sender effects and receiver effects, as well as the 'constant' term for extra reciprocity, do not change much in the empty and final models. Adding explanatory variables for the density parameter reduced the 'constant' term for density, $\mu$, thus accounting for a good part of the differences among attorneys in this network.

17. The negative reciprocity effect of hierarchical status similarity is actually positive. In $\mathrm{p}_{2}$ models, the density effect comes in twice for reciprocal relations. This means that the overall reciprocity effect is still positive $(2 * 0.65-1.03=0.27)$ but is indeed smaller than the effect of status similarity on asymmetric relations (0.65). Compared to the probabilities of non-similar dyads, however, both asymmetric and reciprocal relations are higher.

18. Other mechanisms that are not quantified here (and which are therefore included in the 'random' part of the model) operate as well.

19. In our view, the analysis in terms of structural equivalence describes the transfers and exchange system for that resource (co-workers' goodwill creating strong work ties). In effect, this simplified representation at the overall level visualizes the flows of that resource across positions of actors who share approximately the same relational profile, i.e. the same sources of co-workers' goodwill. There is no 'mechanical' way of going from the dyadic to the structural level in the description of these flows; therefore this picture only provides one possible description of a transfers and exchange system between positions instead of the same system between individuals. For a complementary description of the exchange system, this time at the level of dyads, triads, and level-4 sub-structures, see Lazega and Pattison (1999).

20. Choices of co-workers create a network of strong work ties. The density of the network is 0.22 , which is much higher than in the 'friendship' and advice networks in the same firm (Lazega, 1992): 88\% of all possible direct and indirect relations are possible in two steps. The cost of having interaction, or access to cooperation, with most people (except with one isolate) is low in general. Approximation of structural equivalence for this specific network uses Euclidean distances and takes into account indirect ties (Burt, 1982, 1991).

21. The office boundary will not be the centre of attention here: the two offices were not large enough to survive individually as a general practice firm, which is why they had merged eight years earlier.

22. This definition does not include a small 'boutique' that could not survive on its own but that could be bought out by another firm. Given the size of most firms in the region, this case can be assimilated to a more or less individual defection, which is not the topic of this paper.

23. Performance is measured by dollars brought in during 1990, the year before fieldwork began. Centrality scores are in-degree measures in the co-workers' network. Top performers are lawyers who rank between first and fifteenth in the first measure. Central lawyers are those who receive more than 20 citations in the second measure.

24. Associates, the grinders, are represented by Position Three on the litigation side and Five on the corporate side. These are two pools of associates for whom it is difficult to distinguish individual clientelistic ties with specific partners; I also include here a position of lateral senior associates on the corporate side (Position Seven) who work with all the corporate partners in the firm.

25. Describing the relationship between defection and other types of opportunistic behaviour, such as shirking, is beyond the scope of this paper. Reactions to shirking have been examined elsewhere (Lazega, 1995a; Lazega and Vari, 1992; Lazega and Lebeaux, 1995; Lazega, 2000).

26. Burt (1982) defines a 'residual' member as an actor whose relational profile is unique, i.e. too different from that of others. This expression can be misleading since some of these members are top performers and very central.

\section{Acknowledgements}

This paper was written while working at Lasmas-Cnrs in Paris and first presented at the conference The Management of Durable Relations Within and Between Organizations, organized by Werner Raub and Jeroen Weesie, ICS, Utrecht University, 1997. I thank Marijtje 
van Duijn and Tom Snijders for help and advice with the analysis of the data. Vincent Buskens, Henk Flap, Siegwart Lindenberg, Harrison White, Rafael Wittek, and two anonymous reviewers provided helpful comments on a previous draft. Fieldwork was funded by the Swiss National Foundation for Scientific Research and is gratefully acknowledged.

\section{References}

Blau, P. M. (1964) Exchange and Power in Social Life. John Wiley, New York.

Blossfeld, H.-P. and Prein, G. (1998) (eds.) Rational Choice Theory and Large Scale Data-Analysis. Westview, Boulder, Colo.

Boudon, R. (1981) La Logique du social. Presses Universitaires de France, Paris.

Burt, R. S. (1982) Toward a Structural Theory of action. Academic Press, New York.

Burt, R. S. (1991) STRUCTURE 4.2. Center for the Social Sciences, Columbia University, New York.

Burt, R. S. (1992) Structural Holes: A Study of the Social Structure of Competition. Harvard University Press, Cambridge, Mass.

Coleman, J. S. (1990) Foundations of Social Theory. Harvard University Press, Cambridge, Mass.

Crozier, M. and Friedberg, E. (1977) L'Acteur et le système. Seuil, Paris.

Eccles, R. G. and Crane, D. B. (1988) Doing Deals: Investment Banks at Work. Harvard Business School Press, Boston.

Eickemeyer, J. H. (1988) Law Firms Agreements and Disagreements. Practicing Law Institute, New York.

Esser, H. (1998) Why are bridge hypotheses necessary?. In Blossfeld, H.-P. and Prein, G. (eds.), Rational Choice Theory and Large Scale Data-Analysis. Westview, Boulder, Colo.

Flap, H. D. (1988) Conflict, Loyalty and Violence: Social Networks in Stateless Societies. Peter Lang, Bern.

Flap, H. D. (1990) Patronage: an institution in its own right. In Hechter, M., Opp, K. -D., and Wippler, R. (eds.) Social Institutions: Their Emergence, Maintenance and Effects. Walter de Gruyter, New York.

Flap, H. D. and De Graaf, N. D. (1989) Social capital and attained occupational status. Netherlands Journal of Sociology, 22, 145-161.

Frank, R. H. (1985) Choosing the Right Pond: Human Behavior and the Quest for Status. Oxford University Press, Oxford.

Freidson, E. (1976) The division of labor as social interaction. Social Problems, 23, 304-313.
Galanter, M. and Palay, T. (1991) Tournament of Lawyers: The Transformation of the Big Law Firm. University of Chicago Press, Chicago.

Gilson, R. J. and Mnookin, R. H. (1985) Sharing among human capitalists: an economic inquiry into the corporate law firm and how partners split profits. Stanford Law Review, 37, 313-392.

Hechter, M. (1987) Principles of Group Solidarity. University of California Press, Berkeley, Calif.

Hedström, P. and Swedberg, R. (1998) Rational choice, situational analysis, and empirical research. In Blossfeld, H. -P. and Prein, G. (eds), Rational Choice Theory and Large Scale Data-Analysis. Westview, Boulder, Colo.

Kuty, O. (1998) La Négociation des valeurs. De Boeck and Larcier, Brussels.

Laumann, E. O. and Heinz, J. P. (1977) Specialization and prestige in the legal profession: the structure of deference. American Bar Foundation Research Journal, 1, 155-216.

Lazega, E. (1992) Analyse de réseaux d'une organisation collégiale: les avocats d'affaires. Revue Française de Sociologie, 33, 559-589.

Lazega, E. (1993) Bureaucratie et collégialité dans les firmes américaines d'avocats d'affaires. Droitet Société, 23/24, 15-40.

Lazega, E. (1995a) Protecting the Common Good Among Equals: A Lateral Control Regime of Partners in a Law Firm. LASMAS Preprint no. 96/1, Paris.

Lazega, E. (1995b) Concurrence, coopération et flux de conseils dans un cabinet américain d'avocats d'affaires: les échanges d'idées entre collègues. Revue Suisse de Sociologie, 21, 61-84.

Lazega, E. (1999a) Generalized exchange and economic performance: social embeddedness of labor contracts in a corporate law firm. In Leenders, R. and Gabbay, S. (eds.) Corporate Social Capital and Liabilities. Kluwer, Boston.

Lazega, E. (1999b) Le Phénomène collégial: une théorie structurale de l'action collective entre pairs. Revue Française de Sociologie, 40, 639-670.

Lazega, E. (2000) Enforcing rules among peers: a lateral control regime. Organisation Studies, 21, 193-214.

Lazega, E. (forthcoming) The CollegialPhenomenon. Oxford University Press, Oxford.

Lazega, E. and Krackhardt, D. (2000) Spreading and shifting costs of lateral control in a law partnership: A structural analysis at the individual level. Quality and Quantity, 34, 153-175.

Lazega, E. and Vari, S. (1992) Acteurs, cibles et leviers: analyse factorielle de réseaux de contrôle dans une firme américaine d'avocats d'affaires. Bulletin de Méthodologie Sociologique, 37, 41-51. 
Lazega, E. and Lebeaux, M.-O. (1995) Capital social et contrainte latérale. Revue Française de Sociologie, 36, 759-77.

Lazega, E. and Van Duijn, M. (1997) Position in formal structure, personal characteristics and choices of advisors in a law firm: a logistic regression model for dyadic network data. Social Networks, 19, 375-397.

Lazega, E. and Pattison, P. E. (1999) Multiplexity, generalized exchange and cooperation in organizations: a case study. Social Networks, 21, 67-90.

Lin, N. and Dumin, M. (1986) Access to occupations through social ties. Social Networks, 8, 365-385.

Lindenberg, S. and Wippler, R. (1978) Theorienvergleich: elementen des rekonstruktion. In Hondrich, K. O. and Matthes, J. (eds.) Theorienvergleich in den Sozialwissenschaften. Luchterhand, Darmstadt.

Lindenberg, S. (1998) Solidarity: Its Microfoundations and Macro Dependence: A Framing Approach. In P. Doreian and T. J. Fararo (eds.) The Problem of Solidarity: Theories and Models. Gordon \& Breach, London.

Michels, R. [1915] (1962) Political Parties: A Sociological Study of the Oligarchical Tendencies of Modern Democracy. The Free Press, New York.

Morrill, C. (1995) The Executive Way: Conflict Management in Corporations. University of Chicago Press, Chicago.

Nelson, R. L. (1988) Partners with Power: The Social Transformation of the Large Law Firm. University of California Press, Berkeley.

Pitt-Rivers, J. A. (1954) The People of the Sierra. Weidenfeld and Nicolson, London.

Raub, W. and Weesie, J. (1990) Reputation and efficiency in social interactions: an example of network effects. American Journal of Sociology, 96, 626-654.

Rowley, S. and Rowley, R. [1916] (1960) Rowley on Partnership. Bobbs-Merrill, New York.

Sciulli, D. (1986) Theory of Societal Constitutionalism. Cambridge University Press, Cambridge.
Smigel, E. (1969) The Wall Street Lawyer: Professional Organizational Man? 2nd edn. Indiana University Press, Bloomington, Ind.

Sutton, R. I. and Hargadon, A. (1996) Brainstorming groups in context: effectiveness in a product design firm. Administrative Science Quarterly, 41, 685-718.

Van Duijn, M. (1995) Estimation of a random effects model for directed graphs. In Toeval zit Overall, Programmatuur voor Random-Coëfficiënt Modellen. Zevende Symposium Statistische Software, Groningen: ProGAMMA.

Van Duijn, M. and Snijders, T. (1996) A random effects model with covariates for directed graphs. Under review.

Waters, M. (1989) Collegiality, bureaucratization, and professionalization: a Weberian analysis. American Journal of Sociology, 94, 945-972.

Waters, M. (1993) Alternative organizational formations: a neo-Weberian typology of polycratic administrative systems. The Sociological Review, 41, 55-81.

White, H. C. (1985) Agency as control. In Pratt, J. W. and Zeckhauser, R. (eds.) Principles and Agents: The Structure of Business. Harvard University Press, Boston.

\section{Appendix: Spotting RED ('Ready-for- Easy-Defection') Subsets}

This appendix presents a density table (Table A1) relating to Figure 1 and a description of positions of approximately structurally equivalent members in the strong co-workers' network. The density table (constructed with STRUCTURE 4.1. (Burt, 1991)) is for the co-workers' network, where cell $i$,

Table A1. Density table for the co-workers' network presented in Figure 1

\begin{tabular}{|c|c|c|c|c|c|c|c|c|c|c|c|}
\hline Position & 1 & 2 & 3 & 4 & 5 & 6 & 7 & 8 & 9 & 10 & Residual \\
\hline 1 & 0.715 & 0.397 & 0.130 & 0.124 & 0.060 & 0.162 & 0.214 & 0.259 & 0.369 & 0.203 & 0.231 \\
\hline 2 & 0.368 & 0.647 & 0.057 & 0.380 & 0.131 & 0.071 & 0.392 & 0.187 & 0.108 & 0.304 & 0.340 \\
\hline 3 & 0.092 & 0.088 & 0.420 & 0.174 & 0.095 & 0.418 & 0.144 & 0.582 & 0.344 & 0.178 & 0.209 \\
\hline 4 & 0.081 & 0.234 & 0.154 & 0.639 & 0.418 & 0.116 & 0.325 & 0.281 & 0.182 & 0.556 & 0.228 \\
\hline 5 & 0.067 & 0.149 & 0.108 & 0.636 & 0.291 & 0.089 & 0.184 & 0.279 & 0.199 & 0.374 & 0.217 \\
\hline 6 & 0.131 & 0.086 & 0.368 & 0.210 & 0.128 & 0.313 & 0.149 & 0.460 & 0.456 & 0.277 & 0.233 \\
\hline 7 & 0.133 & 0.286 & 0.127 & 0.583 & 0.164 & 0.129 & 0.643 & 0.126 & 0.100 & 0.526 & 0.157 \\
\hline 8 & 0.176 & 0.093 & 0.471 & 0.276 & 0.140 & 0.315 & 0.134 & 0.232 & 0.492 & 0.253 & 0.179 \\
\hline 9 & 0.235 & 0.052 & 0.285 & 0.214 & 0.138 & 0.406 & 0.108 & 0.522 & 0.122 & 0.183 & 0.231 \\
\hline 10 & 0.100 & 0.147 & 0.136 & 0.477 & 0.224 & 0.183 & 0.563 & 0.331 & 0.041 & 0.204 & 0.256 \\
\hline Residual & 0.232 & 0.229 & 0.113 & 0.210 & 0.161 & 0.099 & 0.116 & 0.338 & 0.231 & 0.231 & 0.278 \\
\hline
\end{tabular}


Table A2. Image matrix relating to Figure 1

\begin{tabular}{|c|c|c|c|c|c|c|c|c|c|c|}
\hline Position & 1 & 2 & 3 & 4 & 5 & 6 & 7 & 8 & 9 & 0 \\
\hline 1 & 1 & 1 & 0 & 0 & 0 & 0 & 0 & 1 & 1 & 0 \\
\hline 2 & 1 & 1 & 0 & 1 & 0 & 0 & 1 & 0 & 0 & 1 \\
\hline 3 & 0 & 0 & 1 & 0 & 0 & 1 & 0 & 1 & 1 & 0 \\
\hline 4 & 0 & 0 & 0 & 1 & 1 & 0 & 1 & 1 & 0 & 1 \\
\hline 5 & 0 & 0 & 0 & 1 & 1 & 0 & 0 & 1 & 0 & 1 \\
\hline 6 & 0 & 0 & 1 & 0 & 0 & 1 & 0 & 1 & 1 & 1 \\
\hline 7 & 0 & 1 & 0 & 1 & 0 & 0 & 1 & 0 & 0 & 1 \\
\hline 8 & 0 & 0 & 1 & 1 & 0 & 1 & 0 & 0 & 1 & 1 \\
\hline 9 & 0 & 0 & 1 & 0 & 0 & 1 & 0 & 1 & 0 & 0 \\
\hline 10 & 0 & 0 & 0 & 1 & 0 & 0 & 1 & 1 & 0 & 0 \\
\hline
\end{tabular}

$j$ is the average relation from someone occupying position I to someone in position J. The average relation between any two people in the network is 0.237 .

Table A2 presents an image matrix, i.e. a simplified and reduced form of the above density table, which is based on cutoff at the overall density of the network (cell $i, j=1$ if cell $i, j$ density is greater than the average relation in the network between any two people). Figure 1 represents the best (i.e. 'cleanest') split into positions approximating structural equivalence between members in this network.

Position One includes six partners and three associates, all Office II litigators. Average amounts collected for the firm is $\$ 260 \mathrm{~K}$ per partner, average indegree centrality is 16 and 15 for partners in the coworkers' and advice networks respectively (which is high for Office II members). Among them, partners 5 and 18 are among the top performers in the firm, and partner 32 - who represents the ATC committee in Office II - among the most central partners in the co-workers' network. ${ }^{25}$ They work together closely, forming a more or less permanent team. They also work with Position Two members (same office, different specialty), with Position Eight (high status partners, same specialty, different office) and Position Nine (senior associates, same specialty, different office). Through Positions Eight and Nine, they can get access - when additional workforce is needed on large and urgent cases - to Position Three members, a pool of more junior litigation associates in the other office. Associates 51, 58, and 59 can be considered to be clients of Position One partners, especially 5 and 18 . In this network, they may also benefit from their proximity with Partner 32.

Position Two includes five partners and two associates, all Office II corporate lawyers, among which Partner 14, a top performer, and partner 28, a very central partner in the network. Average amounts collected for the firm is $\$ 229 \mathrm{~K}$ per partner, average indegree centrality is 16 and 14 for partners in the co-workers' and advice networks respectively (which is high for Office II members). Members who work together, as well as with Position One litigators (same office, different specialty), with Positions Four and Ten (high status partners, same specialty, different office), and with Position Seven (a set of highly competent lateral associates, same specialty, different office). Through Position Four and Seven, Position Two can get access - when additional workforce is needed on large and urgent cases - to Position Five members, a pool of more junior corporate associates in the other office. Associates 50 and 63 can be considered to be clients of this position partners, especially 14 and 28 .

Position Three includes one partner (partner 21, a top performer) and eight associates, all Office I litigators. This a less cohesive position, in which members work with one another-sometimes around partner 21, for instance - but less so than members of the previous positions. They constitute a pool of manpower working mainly for Positions Six and Eight, i.e. Office I litigation partners and their Position Nine brokers (senior associates in the same office). Position Three members show that the patronage system is a two tiered system; they are 
clients of clients who do not (yet) belong to close knit stable teams.

Position Four includes six Office I corporate partners, among which Partners 12, 17, and 19 are top performers, and Partners 16, 17, 19, 29, and 34 are highly central. Average amounts collected for the firm is $\$ 251 \mathrm{~K}$ per partner, average indegree centrality is 24 and 20 in the co-workers' and advice networks respectively. They distribute work to Position Five associates (same office, same specialty), and to their senior and lateral associates of Position Seven (same office, same specialty). They work with Position Eight partners (same office, different specialty) and with Position Ten partners (same office, same specialty). This position is highly cohesive and concentrates much power but does not seem to have its own clientele. Positions Five and Seven's associates are shared with other partners, especially from Positions Eight and Ten. They do not consider Position Two members (same specialty, different office) as strong co-workers: there are more people in Office I, and thus more different specialties represented, and they do not feel that they need to strengthen Office II corporate group.

Position Five includes mainly corporate associates in Office I and Office III, mixed with associates working mainly with Office I Positions Four and Ten (same office, same specialty partners) and with Position Eight (same office, different specialty partners). Partner 2, a top performer, is also a member of this position. This is mainly a workforce pool in which it is difficult to distinguish close clientelistic ties with specific partners. In particular, senior corporate associates of Position Seven, mostly laterals, do not operate as brokers between these associates and the partners; in addition, just as Position Three associates, they do not work much for Office II corporate partners.

Position Six includes closely tied Office I litigation partners (among which Partner 1, a top performer, two other partners working with him, and Associate 52, a very central broker between Partner 1 or Partner 23 and other associates) and associates, another stable team in the firm. Average amounts collected for the firm is $\$ 225 \mathrm{~K}$ per partner, average indegree centrality is 12 and 16 in the coworkers' and advice networks respectively. Partners in this position control large clients and provide both their own associates, as well as Position Eight partners and Position Three associates with work. They use Position Nine senior associates and collaborate with corporate partners in their own office (Position Ten), but not with Position Four. This stable team subcontracts a lot of work, but not to Office II litigators, with whom they do not feel much solidarity.

Position Seven includes senior corporate associates in the firm, almost all laterals, among whom Associate 45, one of the most central attorneys in the firm. They are not part of a stable team, nor seem to be clients of specific partners. They are more senior than most Position Five associates, and have a specific structural position in that they work with/for the three positions of corporate partners in the firm (Positions Two, Four, and Ten), without exception: they were hired based on their indispensable specialties. Because they did not 'grow up' in the firm, they seem to have more autonomy in their choices of collaborators, depending less on one or two specific patrons. Their relationship with the other lawyers in the firm is more impersonal and functional.

Position Eight includes Office I partners, mainly litigators, who have in common that they are closer to most associates in the firm, either because they belong to the associate committee on the litigation side (one of their duties being to match associates, partners and new files). They include two top performers, Partners 13 and 26, and four among the most central lawyers in the firm, Partners 13, 22, 24, and 26. Average amounts collected for the firm is $\$ 221 \mathrm{~K}$ per partner, average indegree centrality is 24 and 26 in the co-workers' and advice networks respectively. They work with many positions, although more with litigators in Office I, Positions Three and Six (same specialty, same office), corporate lawyers in Office I (Positions Four and Ten) than in Office II, and they use Position Nine's senior associates. They are recognized as representatives of the good citizens in the firm, in charge of the welfare system for associates, and do not seem to groom their own clients.

Position Nine members includes senior litigation associates in Office I. As with Position Seven's senior corporate associates, they work very little together. But they are very central intermediaries between partners and more junior associates in this network. One of them, Associate 38, reaches one of the 
highest scores in that respect. They redistribute work mainly among Position Three associates, work directly with Positions Six and Eight partners, and control a considerable part of partners'access to manpower, particularly in Office II, where they depend less on partners for their promotion to partnership than in their own office (Office I), where partners are twice as many. They must therefore maintain a fragile balance between many constituencies.

The last position, Position Ten, includes three senior corporate partners in Office I, among whom Partner 4, a top performer with some of the highest centrality scores in this network. Average amounts collected for the firm is $\$ 267 \mathrm{~K}$ per partner, average indegree centrality is 20 and 11 in the co-workers'and advice networks respectively. They do not work together, but collaborate with members of Positions Two, Four, Five, Seven, and Eight. They also represent a structural bridge between corporate and litigation lawyers, which contributes to explain why they have a position of their own.

A 'residual' category ${ }^{26}$ includes seven partners, among whom the managing partner of the firm, and one associate. Three of the partners, Partners 7, 8 , and 15 , are among the top performers, and two, Partners 15 and 30, are among the highest centrality scores. Some work mostly alone, whereas others are highly active in the work distribution process.

\section{Author's Address}

Institut de sociologie and Clersé-Cnrs, Université de Lille 1, Cité scientifique, 59655 Villeneuve d'Ascq cedex. Tel: (00 333) 201258 60; e-mail: emmanuel.lazega@ univ.lille1.fr.

Manuscript received: January 1999. 